\title{
Community metabolism and nutrient cycling in the Mississippi River plume: evidence for intense nitrification at intermediate salinities
}

\author{
J. D. Pakulski ${ }^{1}$, R. Benner ${ }^{1}$, R. Amon ${ }^{1}$, B. Eadie $^{2}$, T. Whitledge ${ }^{1}$ \\ ${ }^{1}$ University of Texas at Austin Marine Science Institute, Port Aransas, Texas 78373, USA \\ ${ }^{2}$ Cooperative Institute for Limnology and Ecosystem Research, NOAA Great Lakes Environmental Research Laboratory, \\ 2205 Commonwealth Blvd, Ann Arbor, Michigan 48105, USA
}

\begin{abstract}
Community respiration, net nutrient fluxes and heterotrophic bacterial production were investigated in the Mississippi River (USA) plume during May 1992 using dark bottle incubations of unfiltered water. Highest rates of community $\mathrm{O}_{2}$ consumption and dissolved inorganic carbon regeneration were observed at intermediate ( 10 to $27 \%$ ) plume salinities. Plume surface $\mathrm{O}_{2}$ consumption rates were 2 - to 4 -fold greater than rates reported previously during the summer and winter. Heterotrophic bacterial production $\left(\left[{ }^{3} \mathrm{H}\right]\right.$-leucine incorporation) was also highest at intermediate salinities and 2- to 4 -fold greater than rates reported from other seasons. Net regeneration of $\mathrm{NH}_{4}{ }^{+}$was observed in the 0 to $18 \%$ region of the plume while low rates of net $\mathrm{NH}_{4}{ }^{+}$consumption were observed at $27 \%$. $\mathrm{Net}^{\mathrm{NO}_{2}}{ }^{-}$ regeneration in the Mississippi River suggested the occurrence of nitrification in the fresh waters of the delta. Serendipitous observations of rapid $\mathrm{NO}_{3}{ }^{-}$regeneration at 18 and $27 \%$ indicated the development of intense nitrification at intermediate plume salinities. Nitrification accounted for 20 to $>50 \%$ of the community $\mathrm{O}_{2}$ demand at 18 and $27 \%$. These data indicated that nitrification was an important component of the plume nitrogen cycle and contributed significantly to oxygen consumption in the plume.
\end{abstract}

KEY WORDS: Mississippi River plume $\cdot$ Bacteria $\cdot$ Nitrification $\cdot$ Respiration $\cdot$ Nutrient cycling

\section{INTRODUCTION}

Nutrient-rich water originating from the Mississippi and Atchafalaya Rivers (USA) supports high levels of primary production in the northern Gulf of Mexico (Riley 1937, Lohrenz et al. 1990). Historical data indicate that nutrient concentrations and ratios in the Mississippi River have changed dramatically over the last 40 years primarily as the result of increased fertilizer use in the Mississippi River watershed (Turner \& Rabalais 1991, Bratkovich \& Dinnel 1992). It has been hypothesized that anthropogenic increases in nutrient inputs from the Mississippi and Atchafalaya Rivers have enhanced primary production in adjacent coastal waters. Sedimentation of organic matter derived from nutrient-enhanced primary production, and strengthened stratification of the water column in the summer months, contribute to the seasonal formation of large areas of hypoxic $\left(<60 \mu \mathrm{M} \mathrm{O}_{2}\right)$ bottom water on the inner Louisiana shelf (Turner \& Rabalais 1991). The formation of these hypoxic waters adversely affects the abundance and diversity of fishes and benthic organisms in the areas affected by these events (Harper et al. 1981, Pavela et al. 1983, Gaston 1985, Renard 1986).

The discharge of the Mississippi River from the Mississippi Delta results in the formation of a broad unconfined plume of low salinity water extending southwest from the delta along the inner Gulf shelf. Mississippi River waters entering the Gulf of Mexico are characterized by high concentrations ( 50 to $100 \mu \mathrm{M}$ ) of nitrate and suspended particulate matter $\left(\sim 60 \mathrm{mg} \mathrm{l}^{-1}\right.$; Lohrenz et al. 1990). Due to the turbidity of the Mississippi River, the distribution of primary production along the plume salinity gradient is influenced primarily by light availability at lower plume salinities and nutrient availability at higher salinities (Lohrenz et al. 1990). As a 
result of the interaction of light and nutrient availability along the plume salinity gradient, highest chlorophyll concentrations and rates of photosynthesis within the plume are observed at intermediate (10 to $30 \%$ ) plume salinities (Lohrenz et al. 1990, Dagg \& Whitledge 1991, Dortch et al. 1992a, Hitchcock \& Whitledge 1992). As a consequence of the distribution of primary production across the plume salinity gradient, bacterial abundances and production (Chin-Leo \& Benner 1992, Cotner \& Gardner 1993) and mesozooplankton abundances (Dagg \& Whitledge 1991) are also highest at intermediate plume salinities, particularly in spring and summer.

It has been hypothesized that $\mathrm{N}$ regeneration within the plume may greatly amplify the effect of $\mathrm{N}$ loading from the Mississippi River on the inner Louisiana shelf (Turner \& Rabalais 1991, Dortch et al. 1992a). The often nonconservative distribution of $\mathrm{N}$ and other nutrients across the plume salinity gradient suggests rapid uptake and cycling of these materials at intermediate salinities (Fox et al. 1987, Lohrenz et al. 1990, Dagg \& Whitledge 1991). Rapid cycling of nutrients within the plume may influence nutrient ratios and the spatial distribution of 'new' $\left(\mathrm{NO}_{3}{ }^{-}\right.$-based) and 'regenerated' $\left(\mathrm{NH}_{4}{ }^{+}\right.$-based; Dugdale \& Goering 1967) primary production across the plume salinity gradient. Variation in nutrient ratios resulting from differential nutrient uptake and regeneration along the plume salinity gradient may further influence the size distribution or species composition of the phytoplankton community (e.g. fast-sinking diatoms vs slow-sinking phytoflagellates and cyanobacteria) and consequently the flux of particulate organic matter from the plume to the benthos (Dortch et al. 1992b).

Bacteria contribute to both community respiration (Chin-Leo \& Benner 1992) and $\mathrm{NH}_{4}{ }^{+}$regeneration (Cotner \& Gardner 1993) within the plume. Bacterial $\mathrm{NH}_{4}{ }^{+}$regeneration rates are highest at intermediate plume salinities in summer (Cotner \& Gardner 1993). Community $\mathrm{NH}_{4}{ }^{+}$regeneration rates, however, can greatly exceed the rates of either $\mathrm{NO}_{3}{ }^{-}$or $\mathrm{NH}_{4}{ }^{+}$uptake, particularly at intermediate salinities (Dortch et al. 1992a).

Organisms in the $>1.0 \mu \mathrm{m}$ size fraction account for 44 to $68 \%$ of community $\mathrm{O}_{2}$ consumption at intermediate plume salinities in summer (Benner et al. 1992), suggesting that bacteria may not be the principal consumers of $\mathrm{O}_{2}$ within the plume. The high concentrations of phyto- and mesozooplankton (Lohrenz et al. 1990, Dagg \& Whitledge 1991) typically present at intermediate salinities may thus contribute substantially to plume community $\mathrm{O}_{2}$ consumption. In addition, there is some evidence for nitrification in the fresh waters of the Mississippi River delta (Fox et al. 1987). The intensity of nitrification and its contribution to both community $\mathrm{O}_{2}$ consumption and $\mathrm{N}$ cycling within the Mississippi River plume, however, are not known. In this report, we present the results of short-term (12 to $24 \mathrm{~h}$ ) dark bottle incubation experiments in which $\mathrm{O}_{2}$ consumption, dissolved inorganic carbon (DIC) production, bacterial abundance and production, and associated net fluxes of $\mathrm{N}$ and $\mathrm{P}$ were measured across the salinity gradient of the Mississippi River plume.

\section{MATERIALS AND METHODS}

Study site and sampling procedures. Sample collections and experiments were conducted from May 4 to 13, 1992, aboard the RV 'Longhorn'. Water samples were collected along a transect originating at the Head of Passes in the Mississippi River delta, through Southwest Pass (a major distributary of the delta) and extending southwest into the northern Gulf of Mexico (Table 1). Plume samples were obtained with clean plastic buckets. Bucket samples were collected into a clean ( $2 \mathrm{~N} \mathrm{HCl}$, distilled $\mathrm{H}_{2} \mathrm{O}$ and sample rinsed) polyethylene carboy and mixed prior to experimental incubations. A visible surface diatom bloom was present at $27 \%$. Nutrient samples in the open Gulf of Mexico $(36 \%$ ) were collected at $5 \mathrm{~m}$ using a Niskin bottle equipped with teflon-coated springs. Sample salinities were measured with a Reichert refractometer.

Sample incubation. Mixed water samples were dispensed into clean $\left(1 \mathrm{~N} \mathrm{HCl}\right.$, distilled $\mathrm{H}_{2} \mathrm{O}$ and sample rinsed) $300 \mathrm{ml}$ BOD (biological oxygen demand) bottles and incubated in the dark at ambient temperature in a precision incubator (Fisher Model 146A). At 2 to $6 \mathrm{~h}$ intervals during each experiment, bottles were removed from the incubator for nutrient, DIC and $\mathrm{O}_{2}$ analyses. At each time point, 3 bottles were poisoned with $50 \mu \mathrm{l}$ of saturated $\mathrm{HgCl}$ solution for DIC analyses and 3 to 5 bottles fixed for Winkler $\mathrm{O}_{2}$ determinations. Nutrient concentrations were also determined from 3 bottles at each time point. Nutrient samples were filtered through combusted glass fiber filters (Whatman $\mathrm{GF} / \mathrm{F}$ ) at low vacuum prior to analyses.

Table 1. Location, salinity, and temperature of Mississippi River plume stations sampled during May 1992

\begin{tabular}{|lccc|}
\hline Latitude & Longitude & $\begin{array}{c}\text { Salinity } \\
(\%)\end{array}$ & $\begin{array}{c}\text { Temperature } \\
\left({ }^{\circ} \mathrm{C}\right)\end{array}$ \\
\hline $29^{\circ} 10.26^{\prime} \mathrm{N}$ & $89^{\circ} 15.72^{\prime} \mathrm{W}$ & 0 & 18.9 \\
$28^{\circ} 52.08^{\prime} \mathrm{N}$ & $89^{\circ} 28.31^{\prime} \mathrm{W}$ & 10 & 20.9 \\
$28^{\circ} 51.33^{\prime} \mathrm{N}$ & $89^{\circ} 31.61^{\prime} \mathrm{W}$ & 18 & 21.0 \\
$28^{\circ} 46.58^{\prime} \mathrm{N}$ & $89^{\circ} 30.42^{\prime} \mathrm{W}$ & 27 & 21.9 \\
$27^{\circ} 35.10^{\prime} \mathrm{N}$ & $89^{\circ} 57.49^{\prime} \mathrm{W}$ & 36 & 22.4 \\
\hline
\end{tabular}


Oxygen consumption. Dissolved $\mathrm{O}_{2}$ concentrations were measured by the Winkler method (Carpenter 1965). A single $50 \mathrm{ml}$ aliquot of fixed sample was drawn from each BOD bottle with a volumetric pipette (Oudot et al. 1988) and titrated with a $0.0125 \mathrm{~N}$ solution of $\mathrm{NaS}_{2} \mathrm{O}_{3}$. Titration equivalence points were determined potentiometrically with a Mettler DL-21 autotitrator equipped with a platinum combination electrode (Mettler DM 140-SC; Oudot et al. 1988, Granéli \& Granéli 1991, Pomeroy et al. 1994). Standards were prepared with commercially available $0.025 \mathrm{~N}$ $\mathrm{KH}\left(\mathrm{IO}_{3}\right)_{2}$ solutions (Fischer Scientific). Blanks were equivalent to $<1.5 \mu \mathrm{M}$ dissolved $\mathrm{O}_{2}$ or $<0.8 \%$ total dissolved $\mathrm{O}_{2}$ concentrations. The precision (coefficient of variation) of the sample titrations was $2.4 \%(n=21$ time points). Oxygen consumption rates were determined from the slope of the least-squares linear regression equation calculated for each time course experiment. All data points were included in each regression. Analysis of variance for each regression (including DIC and nutrient data, see below) was performed to determine significant $(\mathrm{p}<0.05)$ slopes.

Dissolved inorganic carbon determination. DIC was measured by coulometry, using sample handling procedures described by Dickson \& Goyet (1991). Samples were transferred from BOD bottles to a stripping chamber prefilled with $4 \mathrm{ml}$ prestripped $15 \% \mathrm{H}_{3} \mathrm{PO}_{4}$. The sample was stripped of DIC into a coulometer cell (UIC, Inc., Model 5120) and automatically titrated to a constant endpoint. Standards were prepared from $\mathrm{Na}_{2} \mathrm{CO}_{3}$. Precision from replicate analysis of standards was $\pm 2.6 \mu \mathrm{mol} \mathrm{kg}^{-1}$. Differences among triplicate water samples were sometimes larger, presumably due to the heterogeneity in the water samples. DIC production rates were determined from the slope of the leastsquares regression line obtained from all time points in each time course experiment.

Nutrient analyses and flux rates. Analyses for $\mathrm{NH}_{4}{ }^{+}$, $\mathrm{NO}_{2}{ }^{-}$and $\mathrm{NO}_{3}^{-}$were performed aboard ship with an Alpkem rapid flow analyzer according to the procedures of Whitledge et al. (1981). Soluble reactive phosphorus (SRP) analyses were performed on thawed samples in the laboratory. Net nutrient flux rates were calculated from the slope of the least-squares regression line from each time course experiment.

Lipshultz et al. (1986) reported that ${ }^{15} \mathrm{~N}$ fluxes measured in the Delaware River were often substantially different between light and dark treatments. We did not evaluate the effect of light on our measurements of community nutrient fluxes. We recognize that lightmediated reactions (e.g. photosynthesis) are important mechanisms influencing the flux and concentrations of dissolved materials in the plume. Dark reactions, however, are equally important on diel time scales. Moreover, in the turbid waters of the Mississippi River plume, particularly at lower plume salinities where light limits photosynthesis, dark reactions may be the dominant factors influencing nutrient cycling.

We further recognize that our estimates of net nutrient flux rates may underestimate absolute (gross) values. In addition, it should be noted that a determination of zero net flux does not necessarily imply zero gross flux as uptake may balance production or regeneration.

Bacterial abundances and production. Bacterial abundances were measured by epifluorescence microscopy of DAPI-stained samples (Porter \& Feig 1980). Bacterial production was determined by $\left[{ }^{3} \mathrm{H}\right]$-leucine incorporation (Kirchman et al. 1985). Leucine incorporation rates were determined at the beginning, middle and end of each time course experiment. At each time point, $10 \mathrm{ml}$ samples from duplicate or triplicate BOD bottles were amended with $\left[{ }^{3} \mathrm{H}\right]$-leucine (New England Nuclear, Boston, MA, USA; $60 \mathrm{mCi} \mathrm{mmol}^{-1} ; 10 \mathrm{nM}$ final concentration) and incubated for $30 \mathrm{~min}$. Initial $(t=0)$ incorporation rates were used to estimate in situ bacterial production at the time of sampling and for comparisons to other rate measurements. The mean coefficient of variation for triplicate bacterial production estimates was $24 \%(n=12)$. Bacterial production estimates were obtained from highly turbid unfiltered samples and sample heterogeneity contributed to higher variances at some time points. Controls were killed with formalin. Leucine incorporation rates were linear up to $60 \mathrm{~min}$ of incubation but were not saturated with addition of $10 \mathrm{nM}$ leucine.

Leucine incorporation rates were converted to bacterial carbon assuming a conversion factor of $3.1 \mathrm{~kg}$ bacterial C produced per mole incorporated leucine (Simon \& Azam 1989). Estimates of bacterial production using the latter conversion factor are comparable to those derived from thymidine incorporation and an empirically derived conversion factor for Mississippi River plume bacteria (Chin-Leo \& Benner 1992). Bacterial respiration rates were estimated assuming an empirically derived leucine incorporation-based growth efficiency of $24 \%$ for Mississippi River plume bacteria (Chin-Leo \& Benner 1992).

\section{RESULTS}

\section{Oxygen consumption and DIC production}

Oxygen consumption and net DIC production rates were not significant $(p>0.05)$ in the Mississippi River (Table 2). Leucine incorporation rates and net nutrient fluxes (below), however, indicated low but measurable microbial activity at this station. Oxygen consumption and DIC production rates measured in the 10 to $27 \%$ region of the plume varied from 0.59 to $3.65 \mu \mathrm{M} \mathrm{O}_{2} \mathrm{~h}^{-1}$ 
Table 2. Dissolved $\mathrm{O}_{2}$ consumption and dissolved inorganic carbon (DIC) production rates from the Mississippi River plume during May 1992. Positive values indicate a net increase and negative values a net decrease in $\mathrm{O}_{2}$ and DIC concentrations

\begin{tabular}{|c|c|c|c|c|c|}
\hline $\begin{array}{c}\text { Salinity } \\
(\%)\end{array}$ & $\begin{array}{l}\text { Flux rate } \\
\left(\mu \mathrm{M} \mathrm{h}^{-1}\right)\end{array}$ & $r^{2}$ & $\mathrm{p}$ & $\mathrm{n}$ & $\begin{array}{l}\text { Incubation time } \\
\text { (h) }\end{array}$ \\
\hline \multicolumn{6}{|c|}{$\mathrm{O}_{2}$ consumption } \\
\hline 0 & $+0.12^{\mathrm{ns}}$ & 0.03 & 0.62 & 12 & 12 \\
\hline 10 & -0.59 & 0.77 & $<0.01$ & 15 & 12 \\
\hline 18 & -3.65 & 0.17 & 0.05 & 21 & 12 \\
\hline 27 & -1.74 & 0,44 & $<0.01$ & 19 & 12 \\
\hline \multicolumn{6}{|c|}{ DIC production } \\
\hline 0 & $-0.18^{\mathrm{ns}}$ & 0.04 & 0.54 & 11 & 12 \\
\hline 10 & +1.47 & 0.48 & 0.04 & 9 & 12 \\
\hline 18 & +3.00 & 0.87 & $<0.01$ & 9 & 12 \\
\hline 27 & +0.85 & 0.68 & $<0.01$ & 9 & 24 \\
\hline
\end{tabular}

and 0.87 to $2.91 \mu \mathrm{M} \mathrm{C} \mathrm{h}^{-1}$, respectively (Table 2). Both DIC production and $\mathrm{O}_{2}$ consumption were greatest at $18 \%$.

\section{Plume heterotrophic bacterial production, respiration and abundances}

Bacterial abundances across the plume salinity gradient ranged from 3.1 to $9.1 \times 10^{5}$ cells ml $^{-1}$ (Table 3 ). Bacterial cell densities were greatest at $10 \%$ and declined at higher salinities. Initial $(t=0)$ bacterial production rates ranged from 0.035 to $0.313 \mu \mathrm{M} \mathrm{C} \mathrm{h}^{-1}$ (Table 2). Bacterial production rates generally increased during the course of the incubations (Fig. 1). The spatial distribution of bacterial production corresponded to the distribution of $\mathrm{O}_{2}$ consumption and DIC production across the plume salinity gradient, with the highest bacterial production rates measured at $18 \%$ (Table 3 ). Estimates of heterotrophic bacterial respiration ranged from 0.15 to $1.30 \mu \mathrm{M} \mathrm{C} \mathrm{h}^{-1}$ (Table 3) and were equivalent to 18 to $45 \%$ of net community DIC production in the 10 to $27 \%$ region of the plume (Table 3 ).

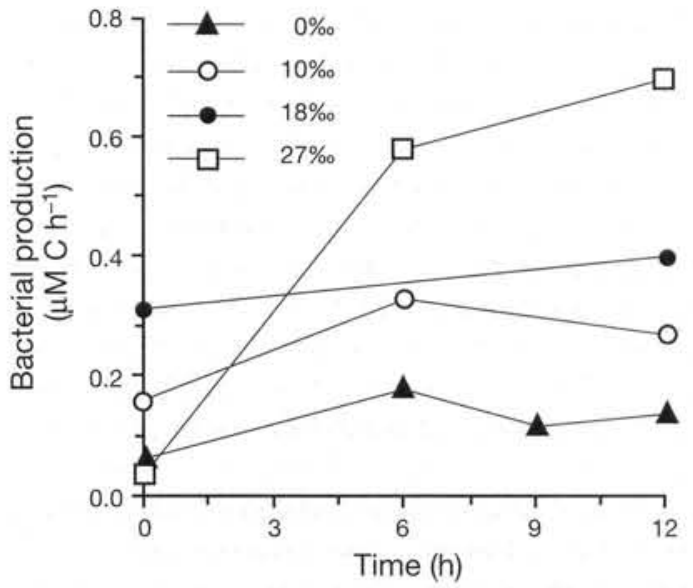

Fig. 1. Time course of bacterial production in experimental incubations of unfiltered Mississippi River plume water, May 1992

\section{Plume nutrient concentrations and net nitrogen fluxes}

Plume $\mathrm{NH}_{4}{ }^{+}$concentrations varied from 0.29 to $2.39 \mu \mathrm{M}$ (Table 4) and exhibited enhanced concentra-

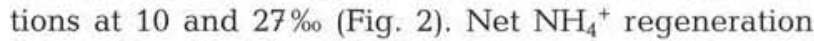
was observed at lower plume salinities with the highest rate recorded at $18 \%$ (Table 5 ). In the $18 \%$ experiment, $\mathrm{NH}_{4}{ }^{+}$concentrations did not change appreciably after $2 \mathrm{~h}$ of incubation. $\mathrm{Net} \mathrm{NH}_{4}{ }^{+}$regeneration at $18 \%\left(0.43 \mu \mathrm{M} \mathrm{h}^{-1}\right)$ was estimated from the statistically significant ( $\mathrm{p}=0.04$, paired $t$-test) increase in $\mathrm{NH}_{4}{ }^{+}$concentration between the time zero and the $2 \mathrm{~h}$ time points. Net uptake of $\mathrm{NH}_{4}{ }^{+}$, however, was observed at $27 \%$ (Table 5 ). The transition between the zones of net $\mathrm{NH}_{4}{ }^{+}$regeneration and net $\mathrm{NH}_{4}{ }^{+}$uptake was coincident with the region of highest plume respiratory activity.

Nitrate exhibited nonconservative behavior across the plume salinity gradient with depressed concentrations at intermediate salinities (Fig. 2). Nitrate concentrations were highest in the Mississippi River (114.6 $\mu \mathrm{M})$ and declined rapidly with increasing salinity (Table 4). Net $\mathrm{NO}_{3}{ }^{-}$uptake was observed in the Missis-

Table 3. Salinity, bacterial abundance, bacterial production, bacterial respiration, and bacterial respiration as percentage of net DIC production for stations sampled in the Mississippi River plume during May 1992. Bacterial respiration was estimated from bacterial production rates assuming a growth efficiency of $24 \%$ (Chin-Leo \& Benner 1992)

\begin{tabular}{|rcccc|}
\hline $\begin{array}{c}\text { Salinity } \\
(\%)\end{array}$ & $\begin{array}{c}\text { Bacterial abundance } \\
\left(10^{5} \text { cells } \mathrm{ml}^{-1}\right)\end{array}$ & $\begin{array}{c}\text { Bacterial production } \\
\left(\mu \mathrm{M} \mathrm{C} \mathrm{h}^{-1}\right)\end{array}$ & $\begin{array}{c}\text { Bacterial respiration } \\
\left(\mu \mathrm{M} \mathrm{C} \mathrm{h}^{-1}\right)\end{array}$ & $\begin{array}{c}\text { Bacterial respiration as } \\
\% \text { DIC production }\end{array}$ \\
\hline 0 & 4.98 & 0.071 & 0.29 & - \\
10 & 9.12 & 0.158 & 0.66 & 45 \\
18 & 8.99 & 0.313 & 1.30 & 43 \\
27 & 7.54 & 0.035 & 0.15 & 18 \\
\hline
\end{tabular}



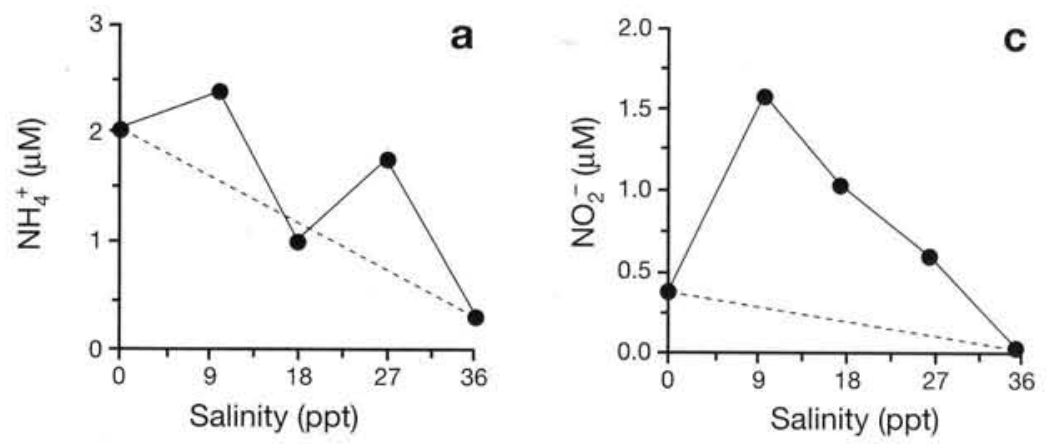

Fig. 2. Property salinity plots for (a) $\mathrm{NH}_{4}{ }^{+}$, (b) $\mathrm{NO}_{2}^{-}$, (c) $\mathrm{NO}_{3}{ }^{-}$, and (d) soluble reactive $\mathrm{P}$ (SRP) from the Mississippi River plume, May 1992. Dashed line connecting salinity end members approximates the conservative mixing distribution
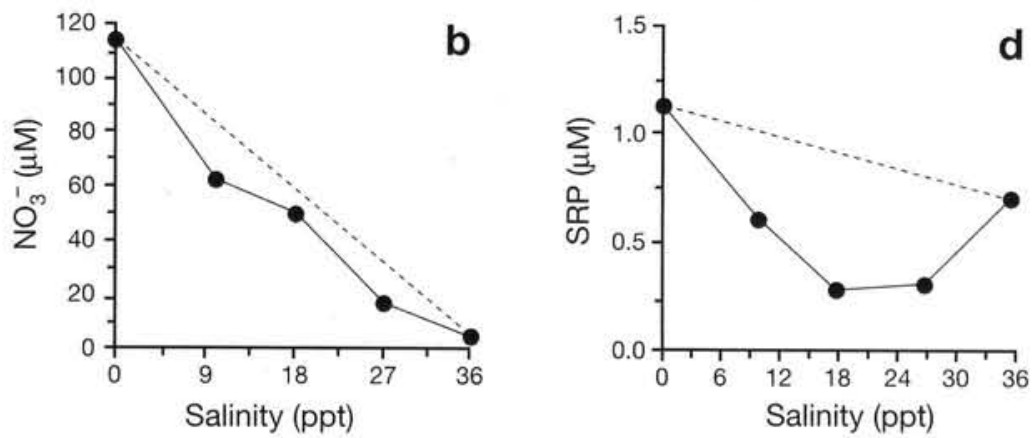

sippi River but there was not significant flux of $\mathrm{NO}_{3}{ }^{-}$at $10 \%$ (Table 5$)$. We observed high rates $(0.37$ and $0.56 \mu \mathrm{M} \mathrm{h}^{-1}$ ) of net $\mathrm{NO}_{3}{ }^{-}$regeneration at 18 and $27 \%$ (Table 5).

Nitrite concentrations varied from 0.01 to $1.56 \mu \mathrm{M}$ (Table 4) and exhibited enhanced concentrations at intermediate salinities (Fig. 2). A significant net regeneration of $\mathrm{NO}_{2}{ }^{-}$was observed in the Mississippi River (Table 5). No significant net fluxes of $\mathrm{NO}_{2}{ }^{-}$, however, were observed in the plume (Table 5).

\section{SRP concentrations}

SRP concentrations varied from 0.28 to $1.40 \mu \mathrm{M}$ and were highest in the Mississippi River (Table 6). Depressed SRP concentrations at intermediate salinities suggested a pronounced P-sink in the 18 to $27 \%$ region of the plume (Fig. 2). Net changes in SRP concentrations were insignificant ( $\mathrm{p}>0.05$, paired $t$-test) over the course of all experimental incubations (Table 6).

\section{Nutrient ratios}

Molar dissolved inorganic $\mathrm{N}\left(\mathrm{DIN}=\mathrm{NH}_{4}{ }^{+}+\mathrm{NO}_{2}{ }^{-}+\right.$ $\mathrm{NO}_{3}{ }^{-}$) to SRP ratios were high in the Mississippi River (103:1) and increased to $183: 1$ at $18 \%$ before declining to $64: 1$ at $27 \%$ (Table 4). The molar DIN:SRP ratio $(5: 1)$ at $36 \%$, however, was substantially lower than those encountered in the plume. Molar $\mathrm{NO}_{3}{ }^{-}: \mathrm{NH}_{4}{ }^{+}$ratios varied considerably across the plume salinity gradient but were higher $(\geq 26: 1)$ at salinities $\leq 18 \%$ ond substantially lower $(\leq 12: 1)$ at 27 and $36 \%$ (Table 4 ).

Table 4. Inorganic nutrient concentrations ( $\pm 1 \mathrm{SD}$ ), and molar DIN $\left(\mathrm{NH}_{4}{ }^{+}+\mathrm{NO}_{2}^{-}+\mathrm{NO}_{3}^{-}\right): \mathrm{SRP}^{-}$and $\mathrm{NO}_{3}^{-}: \mathrm{NH}_{4}{ }^{+}$ratios from the Mississippi River plume during May 1992

\begin{tabular}{|c|c|c|c|c|c|c|c|}
\hline $\begin{array}{c}\text { Salinity } \\
(\% \circ)\end{array}$ & $\begin{array}{l}\mathrm{NH}_{4}{ }^{+} \\
(\mu \mathrm{M})\end{array}$ & $\begin{array}{l}\mathrm{NO}_{2}^{-} \\
(\mu \mathrm{M})\end{array}$ & $\begin{array}{l}\mathrm{NO}_{3}^{-} \\
(\mu \mathrm{M})\end{array}$ & $\begin{array}{l}\text { DIN } \\
(\mu \mathrm{M})\end{array}$ & $\begin{array}{c}\text { SRP } \\
(\mu \mathrm{M})\end{array}$ & DIN:SRP & $\mathrm{NO}_{3}{ }^{-}: \mathrm{NH}_{4}{ }^{+}$ \\
\hline 0 & $2.06 \pm 0.31$ & $0.37 \pm 0.02$ & $114.3 \pm 0.12$ & 116.7 & $1.13 \pm 0.47$ & 103 & 55 \\
\hline 10 & $2.39 \pm 0.44$ & $1.56 \pm 0.43$ & $62.0 \pm 0.64$ & 66.0 & $0.60 \pm 0.15$ & 110 & 26 \\
\hline 18 & $0.81 \pm 0.38$ & $1.01 \pm 0.38$ & $49.5 \pm 0.56$ & 51.3 & $0.28 \pm 0.03$ & 183 & 61 \\
\hline 27 & $1.73 \pm 0.21$ & $0.57 \pm 0.21$ & $16.2 \pm 0.32$ & 18.5 & $0.29 \pm 0.05$ & 64 & 9 \\
\hline 36 & $0.29 \pm 0.10$ & $0.01 \pm 0.00$ & $3.4 \pm 0.00$ & 3.7 & $0.69 \pm 0.05$ & 5 & 12 \\
\hline
\end{tabular}


Table 5. Net $\mathrm{NH}_{4}{ }^{+}, \mathrm{NO}_{2}{ }^{-}$and $\mathrm{NO}_{3}{ }^{-}$flux rates from the Southwest Pass plume of the Mississippi River, May 4-13, 1992. Positive values indicate net production, negative values indicate net uptake

\begin{tabular}{|c|c|c|c|c|c|}
\hline $\begin{array}{l}\text { Salinity } \\
(\%)\end{array}$ & $\begin{array}{l}\text { Net flux rate } \\
\left(\mu \mathrm{M} \mathrm{h}^{-1}\right)\end{array}$ & $r^{2}$ & $\mathrm{p}$ & $\mathrm{n}$ & $\begin{array}{l}\text { Incubation time } \\
\text { (h) }\end{array}$ \\
\hline \multicolumn{6}{|l|}{$\mathrm{NH}_{4}{ }^{+}$} \\
\hline 0 & +0.27 & 0.74 & $<0.01$ & 15 & 12 \\
\hline 10 & +0.40 & 0.77 & $<0.01$ & 9 & 6 \\
\hline 18 & +0.43 & - & $0.04^{a}$ & 3 & 2 \\
\hline 27 & -0.06 & 0.44 & $<0.01$ & 19 & 12 \\
\hline \multicolumn{6}{|l|}{$\mathrm{NO}_{2}^{-}$} \\
\hline 0 & +0.06 & 0.56 & $<0.01$ & 15 & 12 \\
\hline 10 & $-0.03^{\mathrm{ns}}$ & 0.17 & 0.18 & 12 & 9 \\
\hline 18 & $-0.02^{\mathrm{ns}}$ & 0.15 & 0.29 & 9 & 4 \\
\hline 27 & $+0.01^{\mathrm{ns}}$ & 0.28 & 0.14 & 9 & 4 \\
\hline \multicolumn{6}{|l|}{$\mathrm{NO}_{3}^{-}$} \\
\hline 0 & -0.22 & 0.74 & $<0.01$ & 9 & 6 \\
\hline 10 & $-0.03^{\mathrm{ns}}$ & 0.10 & 0.35 & 12 & 12 \\
\hline 18 & +0.37 & 0.50 & $<0.01$ & 12 & 9 \\
\hline 27 & +0.56 & 0.95 & $<0.01$ & 15 & 9 \\
\hline
\end{tabular}

\section{DISCUSSION}

\section{Nitrogen fluxes and nitrification in the Mississippi River plume}

As nitrification in the Mississippi River plume had not been reported previously, we did not anticipate that we would observe net regeneration of $\mathrm{NO}_{3}^{-}$in our incubation experiments. These observations were entirely serendipitous and indicative of intense nitrification. Net regeneration of $\mathrm{NO}_{3}{ }^{-}$at 18 and $27 \%$ in the present investigation was rapid and higher than nitrification $\left(\mathrm{NO}_{2}^{-}+\mathrm{NO}_{3}^{-}\right.$production) rates reported from the Rhône River, France $\left(<0.01\right.$ to $0.18 \mu \mathrm{M} \mathrm{h}^{-1}$; Feliatra $\&$ Bianchi 1993), the Tamar River estuary, UK $(<0.2 \mu \mathrm{M}$ $\mathrm{h}^{-1}$; Owens 1986), and Narragansett Bay, Rhode Island, USA $\left(<0.46 \mu \mathrm{M} \mathrm{h}^{-1}\right.$; Berounsky \& Nixon 1990). A comparison of net $\mathrm{NO}_{3}{ }^{-}$regeneration to net $\mathrm{NH}_{4}{ }^{+}$ and $\mathrm{NO}_{2}{ }^{-}$fluxes at 18 and $27 \%$ (Table 5) further indi-

Table 6. Initial and final concentrations ( \pm 1 SD) of soluble reactive phosphorus (SRP) during experimental incubations of Mississippi River plume waters, May 1992

\begin{tabular}{|cccc|}
\hline $\begin{array}{c}\text { Salinity } \\
(\%)\end{array}$ & $\begin{array}{c}\text { Initial SRP } \\
\text { concentration } \\
(\mu \mathrm{M})\end{array}$ & $\begin{array}{c}\text { Final SRP } \\
\text { concentration } \\
(\mu \mathrm{M})\end{array}$ & $\begin{array}{c}\text { Incubation } \\
\text { time } \\
(\mathrm{h})\end{array}$ \\
\hline 0 & $1.13 \pm 0.47$ & $1.06 \pm 0.09$ & 12 \\
10 & $0.60 \pm 0.15$ & $0.42 \pm 0.19$ & 12 \\
18 & $0.28 \pm 0.03$ & $0.22 \pm 0.02$ & 12 \\
27 & $0.29 \pm 0.05$ & $0.22 \pm 0.01$ & 12 \\
\hline
\end{tabular}

cated that nitrification was a significant component of the plume $\mathrm{N}$ cycle during the period investigated.

Fox et al. (1987), noting elevated $\mathrm{NO}_{2}^{-}, \mathrm{NO}_{3}^{-}$and $\mathrm{N}_{2} \mathrm{O}$ concentrations in the lower salinity (2 to $16 \%$ ) region of the Southwest Pass plume, concluded that nitrification occurred in the Mississippi River upstream from their sampling locations. Net regeneration of $\mathrm{NO}_{2}{ }^{-}$at $0 \%$ in the present investigation also suggested nitrification occurred in the fresh waters of the delta. Although elevated concentrations of $\mathrm{NO}_{2}^{-}$were observed at $10 \%$, the lack of significant net fluxes of $\mathrm{NO}_{2}{ }^{-}$and $\mathrm{NO}_{3}{ }^{-}$suggested nitrification was negligible at this station. The high rates of net $\mathrm{NO}_{3}^{-}$regeneration measured at 18 and $27 \%$, however, indicated the development of intense nitrification at intermediate plume salinities. The above suggested that nitrification along the plume salinity gradient during the present investigation was partitioned between nitrification in the Mississippi River, supported by riverine sources of $\mathrm{NH}_{4}{ }^{+}$, and nitrification within the plume supported by the in situ regeneration of $\mathrm{NH}_{4}{ }^{+}$at intermediate plume salinities.

Although high rates of nitrification were observed at intermediate salinities, $\mathrm{NH}_{4}{ }^{+}$concentrations were low $(<2.5 \mu \mathrm{M})$ across the entire plume salinity gradient. The latter indicated that nitrification at intermediate salinities was supported by the rapid regeneration of $\mathrm{NH}_{4}{ }^{+}$within the plume. Dark net $\mathrm{NH}_{4}{ }^{+}$regeneration rates (Table 5) in the present investigation were similar to dark $\mathrm{NH}_{4}{ }^{+}$regeneration rates $\left(0.05\right.$ to $\left.0.22 \mu \mathrm{M} \mathrm{h}^{-1}\right)$ reported from the plume by Gardner et al. (1994) and ${ }^{15} \mathrm{NH}_{4}{ }^{+}$regeneration rates $\left(<0.05\right.$ to $\left.>4.5 \mu \mathrm{M} \mathrm{h}^{-1}\right)$ obtained under simulated in situ light conditions (Dortch et al. 1992a, Cotner \& Gardner 1993). The distribution of $\mathrm{NH}_{4}{ }^{+}$regeneration reported by the above authors and observed in the present investigation also indicated that $\mathrm{NH}_{4}{ }^{+}$regeneration within the plume is often highest at intermediate salinities where we observed the highest rates of nitrification.

To examine the hypothesis that the rapid remineralization of organic $\mathrm{N}$ supported nitrification at intermediate plume salinities, we compared the mass balance of DIN at the beginning and end of each experimental incubation (Table 7). The mass balance data indicated a net increase in DIN at all stations and

Table 7. Mass balance of DIN during experimental incubation of Mississippi River plume water during May 1992

\begin{tabular}{|ccccc|}
\hline $\begin{array}{c}\text { Salinity } \\
(\%)\end{array}$ & $\begin{array}{c}\text { Initial DIN } \\
(\mu \mathrm{M} \mathrm{N})\end{array}$ & $\begin{array}{c}\text { Final DIN } \\
(\mu \mathrm{MN})\end{array}$ & $\begin{array}{c}\Delta \mathrm{DIN} \\
(\mu \mathrm{MN})\end{array}$ & $\begin{array}{c}\Delta \mathrm{DIN} \mathrm{h}^{-1} \\
\left(\mu \mathrm{M} \mathrm{N} \mathrm{h}^{-1}\right)\end{array}$ \\
\hline 0 & 116.7 & 118.7 & +2.0 & +0.17 \\
10 & 66.0 & 67.6 & +1.6 & +0.13 \\
18 & 51.3 & 54.7 & +3.4 & +0.38 \\
27 & 18.2 & 23.1 & +4.9 & +0.54 \\
\hline
\end{tabular}


Table 8. Comparison of total community DIN fluxes $\left(\mathrm{NH}_{4}{ }^{+}+\mathrm{NO}_{2}{ }^{-}+\mathrm{NO}_{3}{ }^{-}\right)$to $\mathrm{N}$ regeneration estimated from $\mathrm{C}$ remineralization at 18 and $27 \%$. Nitrogen remineralization rates were estimated from DIC production rates assuming Redfield C:N ratios

\begin{tabular}{|cccc}
\hline $\begin{array}{c}\text { Salinity } \\
(\%)\end{array}$ & $\begin{array}{c}\text { Community DIN flux } \\
\left(\mu \mathrm{M} \mathrm{h}^{-1}\right)\end{array}$ & $\begin{array}{c}\mathrm{N} \text { remineralization } \\
(\mathrm{C}: \mathrm{N}=6.625) \\
\left(\mu \mathrm{M} \mathrm{h}^{-1}\right)\end{array}$ & $\begin{array}{c}\text { Difference } \\
\left(\mathrm{DIN} \text { flux }-\mathrm{N}^{\mathrm{N}}(\mu \mathrm{M} \mathrm{hineralization})^{-1}\right)\end{array}$ \\
\hline 18 & 0.82 & 0.44 & 0.38 \\
27 & 0.63 & 0.13 & 0.50 \\
\hline
\end{tabular}

(Bronk \& Glibert 1993). It is not unreasonable, therefore, to hypothesize that the mineralization of urea could contribute to the $\mathrm{NH}_{4}{ }^{+}$regeneration necessary to support the observed nitrification rates in the plume. Thus, within the limitations of our assumptions and the various analytical methods used to estimate our $\mathrm{N}$ fluxes, it

thus a net transformation of organic $\mathrm{N}$ (particulate or dissolved) to DIN. The high rates of net DIN increase observed at 18 and $27 \%$ were consistent with the hypothesis that the rapid remineralization of plumederived organic $\mathrm{N}$ supported nitrification during the period investigated.

We also compared community DIN fluxes (the sum of net $\mathrm{NH}_{4}{ }^{+}, \mathrm{NO}_{2}{ }^{-}$and $\mathrm{NO}_{3}{ }^{-}$flux rates) to $\mathrm{N}$ remineralization rates derived from our estimates of DIC production at 18 and $27 \%$ (Table 8 ). These latter estimates assumed the mineralization of phytoplankton-derived organic matter exhibiting Redfield (6.6) C:N ratios. Estimates of $\mathrm{N}$ remineralization derived from our DIC regeneration rates at 18 and $27 \%$ were 2 - and 5 -fold lower, respectively, than measured community DIN fluxes at these 2 stations (Table 8). These comparisons indicated that $\mathrm{NO}_{3}{ }^{-}$regeneration at 18 and $27 \%$ was not supported solely by the remineralization of organic matter exhibiting Redfield C:N ratios.

We consider below the potential contribution of urea mineralization to our $\mathrm{N}$ fluxes. Urea possesses a $\mathrm{C}: \mathrm{N}$ ratio of 0.5 and is an end product of $\mathrm{N}$ metabolism in many higher organisms including copepods (Corner \& Newell 1967). It is generally assumed that urea is assimilated primarily by phytoplankton (McCarthy 1972). Urea-hydrolyzing bacteria, however, have been isolated from coastal waters (ZoBell \& Feltham 1935).

There is no information available regarding typical concentrations or flux rates of urea in the Mississippi River plume. Dissolved organic nitrogen (DON) concentrations in the plume, however, vary from 12 to $50 \mu \mathrm{M}$ (Lopez-Veneroni \& Cifuentes 1992). Assuming that urea comprises $5 \%$ of DON (Remsen 1971), we estimate that urea concentrations in the Mississippi River plume may be on the order of 0.6 to $2.5 \mu \mathrm{M}$ urea-N. The latter estimates are well within the range of urea concentrations ( 0.5 to $5 \mu \mathrm{M}$ urea-N) observed in coastal waters (McCarthy 1970, Remsen 1971, Kauffman et al. 1983, Kristiansen 1983). Urea mineralization rates required to balance our DIN flux rates at 18 and $27 \%$ would be equivalent to 0.38 and $0.50 \mu \mathrm{M}$ urea- $\mathrm{N} \mathrm{h}^{-1}$, respectively (Table 8). The latter estimates are similar in magnitude to ${ }^{15} \mathrm{~N}$-urea uptake rates (0.10 to $0.29 \mu \mathrm{M} \mathrm{h}^{-1}$ ) measured in Chesapeake Bay appeared that remineralization of plume-derived organic $\mathrm{N}$ would be sufficient to support the high rates of nitrification we observed in these waters.

We hypothesize a sequence whereby the mineralization of particulate organic N (PON) derived from primary production at intermediate plume salinities results in the regeneration of $\mathrm{NH}_{4}{ }^{+}$supporting nitrification. This hypothesis is similar in many respects to a conceptual model of plume bacterial DON remineralization presented by Cotner \& Gardner (1993). In the Mississippi River plume, increasingly favorable light regimes and high concentrations of riverine DIN stimulate photosynthesis and the production of PON at intermediate plume salinities (Lohrenz et al. 1990, Lopez-Veneroni \& Cifuentes 1992). At intermediate and higher salinities, DIN concentrations decline while DON concentrations increase dramatically (LopezVeneroni \& Cifuentes 1992). The above suggests that much of the riverine $\mathrm{NO}_{3}{ }^{-}$assimilated into PON by photoautotrophs at intermediate salinities is subsequently transformed into DON.

Amino acid uptake rates measured during ${ }^{15} \mathrm{NH}_{4}{ }^{+}$ regeneration experiments (Cotner \& Gardner 1993, Gardner et al. 1993) indicate that bacterial remineralization of DON contributes to the regeneration of $\mathrm{NH}_{4}{ }^{+}$ in the plume. Size-fractionation experiments, however, indicate that much of the $\mathrm{NH}_{4}{ }^{+}$regeneration at intermediate plume salinities occurs in the $>1.0 \mu \mathrm{m}$ size fraction (Gardner et al. 1994) suggesting that the mesozooplankton and other larger organisms also contribute to $\mathrm{NH}_{4}{ }^{+}$regeneration within the plume. Mesozooplankton are present in high concentrations (100 to $>1000 \mathrm{I}^{-1}$ ) at intermediate plume salinities (Dagg \& Whitledge 1991) and consume a substantial portion of plume primary production in the late spring and summer months (Dagg \& Ortner 1992, Fahnenstiel et al. 1992). Mesozooplankton may contribute directly to the regeneration of $\mathrm{NH}_{4}{ }^{+}$though excretion, or indirectly through the release of urea and other forms of DON (Corner \& Newell 1967, Lampert 1978, Vidal \& Whitledge 1982, Jumars et al. 1989). Bacterial remineralization of DON and excretion of $\mathrm{NH}_{4}{ }^{+}$by mesozooplankton may thus result in the rapid regeneration of $\mathrm{NH}_{4}^{+}$at intermediate plume salinities. Cotner \& 
Gardner (1993) have further suggested that microbial processes at intermediate plume salinities may regenerate $\mathrm{NH}_{4}{ }^{+}$at rates exceeding phytoplankton uptake. The latter is consistent with the observation by Dortch et al. (1992a) that $\mathrm{NH}_{4}{ }^{+}$regeneration in the light exceeds $\mathrm{NH}_{4}{ }^{+}$uptake over much of the plume salinity gradient. Ammonium regeneration in excess of phytoplankton demand may consequently stimulate the development of nitrification at intermediate salinities.

\section{Distribution of nitrification in the Mississippi River and Rhône River plumes}

The discharge of the Rhône River into the northern Mediterranean Sea results in the formation of a shallow unconfined estuarine plume (Kirchman et al. 1989) similar to the plume originating from the Mississippi River delta. The distribution of DIN concentrations and nitrification rates across the Rhône River plume salinity gradient (Feliatra \& Bianchi 1993), however, differ in many respects from those observed in the Mississippi River plume during the present investigation. Concentrations of $\mathrm{NH}_{4}{ }^{+}(9.83 \mu \mathrm{M}), \mathrm{NO}_{2}^{-}$ $(3.85 \mu \mathrm{M})$, and $\mathrm{NO}_{3}^{-}(112.8 \mu \mathrm{M})$ were highest in the Rhône River and decreased with increasing salinity (Feliatra \& Bianchi 1993). Highest rates of nitrification were also observed in the Rhone River and declined with increasing salinities. In the present investigation, only $\mathrm{NO}_{3}^{-}$exhibited maximal concentrations in the Mississippi River and the highest rates of nitrification occurred at intermediate salinities. Comparison of these 2 plume systems suggests that nitrification in the Rhône River plume was supported by $\mathrm{NH}_{4}{ }^{+}$originating from the Rhône River while nitrification in the Mississippi River plume was associated with in situ $\mathrm{NH}_{4}{ }^{+}$ regeneration at intermediate salinities.

\section{Bacterial metabolism and plume community $\mathrm{O}_{2}$ consumption}

Assuming nitrification consumes $2 \mathrm{~mol} \mathrm{O}_{2}$ per mole of $\mathrm{NH}_{4}{ }^{+}$oxidized to $\mathrm{NO}_{3}{ }^{-}, \mathrm{O}_{2}$ consumption due to nitrification at 18 and $27 \%$ was equivalent to 0.74 and $1.12 \mu \mathrm{M} \mathrm{O}_{2} \mathrm{~h}^{-1}$ (Table 9). The latter rates were similar to the difference between $\mathrm{O}_{2}$ consumption due to carbon remineralization (DIC production) and total community $\mathrm{O}_{2}$ consumption at these stations (Table 9). Thus within the limitations of our estimates of $\mathrm{O}_{2}$ consumption and $\mathrm{NO}_{3}{ }^{-}$regeneration at these stations, nitrification accounted for a substantial portion of community $\mathrm{O}_{2}$ consumption at intermediate plume salinities.
Heterotrophic bacteria are generally considered to be the principle consumers of $\mathrm{O}_{2}$ in marine ecosystems (Williams 1981, 1984, Hopkinson et al. 1989, Griffith et al. 1990). This generalization, however, may not hold true for hypereutrophic systems such as the Mississippi River plume. Jensen et al. (1990) reported that organisms other than heterotrophic bacteria were responsible for $>50 \%$ of community $\mathrm{O}_{2}$ consumption in a highly eutrophic region of a shallow Danish estuary. In the Mississippi River plume, Chin-Leo \& Benner (1992) reported that organisms in the $>1.0 \mu \mathrm{m}$ size fraction accounted for 44 to $68 \%$ of community $\mathrm{O}_{2}$ consumption during the summer, suggesting that larger phytoplankton and zooplankton were responsible for $\sim 50 \%$ of community $\mathrm{O}_{2}$ consumption during this period.

We estimated the contribution of nitrifying bacteria heterotrophic bacteria and other organisms (zooplankton, protozoa and photoautotrophs including cyanobacteria) to community $\mathrm{O}_{2}$ consumption at 18 and $27 \%$. Total community $\mathrm{O}_{2}$ consumption at $18 \%$ was $3.65 \mu \mathrm{M} \mathrm{h}^{-1}$ of which $0.74 \mu \mathrm{M} \mathrm{h}^{-1}$ (Table 9) was attributable to nitrification. Assuming a bacterial growth efficiency of $24 \%$ (Chin-Leo \& Benner 1992) and a respiration quotient (RQ) of $1.0, \mathrm{O}_{2}$ consumption by heterotrophic bacteria at $18 \%$ was estimated to be $1.30 \mu \mathrm{M} \mathrm{h}^{-1}$ (Table 3). Oxygen consumption by other organisms $\left(1.70 \mu \mathrm{M} \mathrm{h}^{-1}\right)$ was estimated as the difference between total community $\mathrm{O}_{2}$ consumption and bacterial (heterotrophs + nitrifiers) $\mathrm{O}_{2}$ consumption. Nitrifying bacteria, heterotrophic bacteria and other organisms thus accounted for 20,36 and $44 \%$, respectively, of community $\mathrm{O}_{2}$ consumption at $18 \%$. Similar estimates indicated that nitrifying bacteria, heterotrophic bacteria and other organisms contributed 64 9 and $27 \%$, respectively, of community $\mathrm{O}_{2}$ consumption at $27 \%$. The above indicated that heterotrophic bacteria were not the principal consumers of $\mathrm{O}_{2}$ at intermediate plume salinities during the period investigated.

We could not evaluate the relative contribution of autotrophs and heterotrophs to the above estimates of $\mathrm{O}_{2}$ consumption not accounted for by heterotrophic and nitrifying bacteria. Packard (1979) and Iriarte et al. (1991), however, have suggested that autotrophic respiration may dominate community respiration where high concentrations of phytoplankton biomass are present. Previous investigations in the Mississippi River plume (Lohrenz et al. 1990, Dagg \& Whitledge 1991, Dortch et al. 1992a, Hitchcock \& Whitledge 1992) have indicated that concentrations of phytoplankton biomass are extremely high (10 to $45 \mu \mathrm{g}$ chl $1^{-1}$ ) at intermediate salinities. Cyanobacteria are also important members of the Mississippi River plume microbial community and are present in concentrations $\left(\sim 10^{5}\right.$ cells $\mathrm{ml}^{-1}$ similar to heterotrophic bacteria 
Table 9. Community $\mathrm{O}_{2}$ consumption, DIC production, $\mathrm{O}_{2}$ consumption not accounted for by carbon remineralization ('excess' $\mathrm{O}_{2}$ consumption = community $\mathrm{O}_{2}$ consumption minus community DIC production, assuming an $\mathrm{RQ}$ of 1), $\mathrm{O}_{2}$ consumption due to nitrification (assumes $2 \mathrm{~mol} \mathrm{O}_{2}$ consumed per mol $\mathrm{NH}_{4}{ }^{+}$oxidized to $\mathrm{NO}_{3}{ }^{-}$and $\mathrm{O}_{2}$ consumption due to nitrification as a percentage of total community $\mathrm{O}_{2}$ consumption at 18 and $27 \%$ )

\begin{tabular}{|cccccc|}
\hline $\begin{array}{c}\text { Salinity } \\
(\%)\end{array}$ & $\begin{array}{c}\text { Community } \mathrm{O}_{2} \\
\text { consumption } \\
\left(\mu \mathrm{M} \mathrm{h}^{-1}\right)\end{array}$ & $\begin{array}{c}\text { Community DIC } \\
\text { production } \\
\left(\mu \mathrm{M} \mathrm{h}^{-1}\right)\end{array}$ & $\begin{array}{c}\text { 'Excess' } \mathrm{O}_{2} \\
\text { consumption } \\
\left(\mu \mathrm{M} \mathrm{h}^{-1}\right)\end{array}$ & $\begin{array}{c}\mathrm{O}_{2} \text { consumption due } \\
\text { to nitrification } \\
\left(\mu \mathrm{M} \mathrm{h}^{-1}\right)\end{array}$ & $\begin{array}{c}\mathrm{O}_{2} \text { consumption due } \\
\text { to nitrification as \% } \\
\left(\% \text { community } \mathrm{O}_{2} \text { consumption }\right)\end{array}$ \\
\hline 18 & 3.65 & 3.00 & 0.65 & 0.74 & 20 \\
27 & 1.74 & 0.85 & 0.89 & 1.12 & 64 \\
\hline
\end{tabular}

(Dortch 1994). Based on our estimates of $\mathrm{O}_{2}$ consumption by the plume community at 18 and $27 \%$, we hypothesize that respiration by photoautotrophs is an important component of community $\mathrm{O}_{2}$ consumption in regions of high phytoplankton biomass.

\section{Implications of nitrification for estimates of plume bacterial production and growth efficiencies}

Our estimates of bacterial production were based on the incorporation of leucine by heterotrophic bacteria. During the period investigated, however, nitrification rates indicated that nitrifying bacteria were also an important component of the plume bacterial community. The ability of nitrifying bacteria to incorporate extracellular leucine has, to our knowledge, not been investigated. Nitrifying bacteria do not incorporate $\left[{ }^{3} \mathrm{H}\right]$-thymidine (Johnstone \& Jones 1989) and it is unlikely, therefore, that they incorporate $\left[{ }^{3} \mathrm{H}\right]$-leucine. Consequently, leucine incorporation rates may not measure the contribution of nitrifying or other autotrophic bacteria (such as cyanobacteria) to total plume bacterial production.

Chin-Leo \& Benner (1992) used leucine incorporation and $\mathrm{O}_{2}$ consumption rates obtained from $1.0 \mu \mathrm{m}$ filtered water samples to empirically estimate plume bacterial growth efficiencies. In the present investigation, we used the mean value of bacterial growth efficiency (24\%) reported by Chin-Leo \& Benner (1992) to estimate heterotrophic bacterial respiration. The latter value is at the low end of the range of bacterial growth efficiencies reported in the literature (20 to $80 \%$; cf. Bjørnsen 1986). Growth efficiencies of heterotrophic bacteria in the Mississippi River plume, however, are variable ( 9 to $42 \%$ ) across the plume salinity gradient and between seasons (Chin-Leo \& Benner 1992). If nitrification contributed to $\mathrm{O}_{2}$ consumption in the experiments conducted by Chin-Leo \& Benner (1992) to estimate bacterial growth efficiencies in the Mississippi River plume, heterotrophic bacterial growth efficiencies would be underestimated. The use of higher bacterial growth efficiencies in our calculations, how- ever, would decrease our estimates of heterotrophic bacterial $\mathrm{O}_{2}$ consumption and further diminish the estimated contribution of heterotrophic bacteria to total community $\mathrm{O}_{2}$ metabolism.

Leucine incorporation rates often increased dramatically over the course of the incubations (Fig. 1). At $10 \%$, community $\mathrm{O}_{2}$ consumption and $\mathrm{NH}_{4}{ }^{+}$regeneration were linear $(r=0.88, p<0.01$ for both) over the course of the incubation whereas leucine incorporation rates increased nearly 2 -fold. Similar observations for community $\mathrm{O}_{2}$ consumption and leucine incorporation rates have been reported by Pomeroy et al. (1994) and Biddanda et al. (1994). The mechanism(s) responsible for these observations remain obscure. The increases in leucine incorporation rates observed in the present investigation indicated that some portion of the heterotrophic bacterial community at $10 \%$ responded quickly to confinement, perhaps through increases in growth efficiency. Changes in leucine incorporation rates at $10 \%$, however, were not reflected in changes in community $\mathrm{O}_{2}$ consumption or $\mathrm{NH}_{4}{ }^{+}$regeneration over the course of this particular experiment.

\section{Influence of Mississippi River discharge on plume bacterial production and community respiration}

Plume heterotrophic bacterial production and $\mathrm{O}_{2}$ consumption rates in the present investigation were 2 - to 4 -fold greater than values measured in February or July (Benner et al. 1992, Chin-Leo \& Benner 1992, Gardner et al. 1994). Higher springtime rates of plume heterotrophic bacterial production and community $\mathrm{O}_{2}$ consumption suggested that these processes may be influenced by higher seasonal discharge from the Mississippi River. By comparing bacterial production in the Mississippi River to bacterial production at intermediate plume salinities, Chin-Leo \& Benner (1992) concluded that plume bacterial production was supported primarily by river-borne substrates in the winter and by phytoplankton-derived substrates in summer. Applying the model employed by Chin-Leo \& Benner (1992) to bacterial production data from the 
present investigation, we estimate that phytoplanktonderived substrates supported $82 \%$ of heterotrophic bacterial production at intermediate plume salinities. The latter suggests that bacterial production observed in the present study was stimulated by enhanced primary production at intermediate salinities rather than by input of organic matter from the river. The distribution of $\mathrm{O}_{2}$ consumption and DIC production also indicated that community respiratory activity was supported by autochthonous production of organic matter at intermediate salinities.

\section{Nutrient limitation, microbial N-cyling and 'new' production in the Mississippi River plume}

While the supply of $\mathrm{N}$ is generally assumed to limit biological production in many marine systems (e.g. Ryther \& Dunstan 1971) the extent of either P- or Nlimitation in coastal marine environments remains unclear (Hecky \& Kilham 1988, Hecky et al, 1993). The results of P-addition experiments (Chin-Leo \& Benner 1992 ) and the rapid turnover of inorganic ${ }^{32} \mathrm{P}$ in Mississippi River plume waters (Ammerman 1992) suggested the potential for P-limitation in the summer and fall. The high ( $>60: 1)$ DIN: SRP ratios observed throughout the plume in the present investigation further suggested the potential for P-limitation of plume bacterial and phytoplankton production in the spring. While inferring nutrient limitation solely from external nutrient ratios is speculative, the above suggests that $\mathrm{P}$ may potentially limit bacterial and primary production in the Mississippi River plume during much of the year.

Turner \& Rabalais (1991) hypothesized that rapid recycling of $\mathrm{N}$ within the plume would amplify the effects of $\mathrm{N}$ loading from the Mississippi River on the inner Gulf shelf. The lower molar $\mathrm{NO}_{3}{ }^{-}: \mathrm{NH}_{4}{ }^{+}$ratios at salinities 27 and $36 \%$ indicated the increasing importance of regenerated DIN at higher plume salinities. The high rates of net $\mathrm{NO}_{3}{ }^{-}$regeneration observed at 18 and $27 \%$ in the present investigation, however, indicated that some portion of the $\mathrm{NO}_{3}{ }^{-}$present at intermediate salinities was regenerated from nitrification and thus not entirely 'new' (i.e. based on the assimilation of riverine or upwelled $\mathrm{NO}_{3}{ }^{-}$) as originally defined by Dugdale \& Goering (1967). Ward et al. (1989) have suggested that the assimilation of $\mathrm{NO}_{3}{ }^{-}$ regenerated via nitrification in the nitricline of the California Bight obscured the distinction between new and regenerated $\mathrm{N}$-based primary production in these waters. The high rates of $\mathrm{NO}_{3}{ }^{-}$regeneration measured at intermediate salinities in the present investigation suggested that measuring 'new' and 'regenerated' primary production based solely on the uptake $\mathrm{NO}_{3}{ }^{-}$may be unreliable in coastal marine ecosystems as well.

\section{Nitrification in the Mississippi River plume: implications for the development of hypoxia on the inner Louisiana shelf}

Evidence from the present investigation indicated that nitrification was an important mechanism contributing to $\mathrm{O}_{2}$ consumption in the Mississippi River plume. Our data further suggested that the high rates of nitrification observed in the present investigation were supported by the rapid remineralization of organic $\mathrm{N}$ derived from nutrient-enhanced primary production at intermediate salinities. Previous research (e.g. Lohrenz et al. 1992) has indicated that $\mathrm{N}$ inputs from the Mississippi and Atchafalaya Rivers support high levels of primary production over extensive areas of the Louisiana shelf subject to the seasonal development of hypoxia. Much of the organic $\mathrm{N}$ derived from nutrient-enhanced primary production on the inner Louisiana shelf may be remineralized to $\mathrm{NH}_{4}{ }^{+}$in deeper waters during periods of enhanced watercolumn stratification in the summer months. We speculate the latter may in turn stimulate nitrification which, in conjunction with $\mathrm{O}_{2}$ consumption resulting from the mineralization of organic $\mathrm{C}$, contributes to the formation of hypoxia in these waters.

Acknowledgements. This research was supported by the Coastal Ocean Program Office of the NOAA through grant NA 90AA-D-SG689 to the Texas Sea Grant Program. The authors thank the following: D. Shorman for the nutrient analyses, M. Lansing for assistance with sampling and DIC analyses, and the crew of the RV 'Longhorn' for their assistance in sampling. University of Texas at Austin Marine Science Institute publication no. 933.

\section{LITERATURE CITED}

Ammerman, J. W. (1992). Seasonal variation in phosphate turnover in the Mississippi River plume and the inner Gulf shelf: rapid summer turnover. Proceedings of the NOAA Nutrient Enhanced Coastal Ocean Productivity Synthesis Workshop, Cocodrie, LA, October, 1991. Texas Sea Grant Publications TAMU-SG-92-109. Texas A\&M University, College Station, p. 69-75

Benner, R., Chin-Leo, G., Gardner, W., Eadie, B., Cotner, J. (1992). The fates and effects of riverine and shelf-derived DOM on the Mississippi River plume/Gulf shelf processes. Proceedings of the NOAA Nutrient Enhanced Coastal Ocean Productivity Synthesis Workshop, Cocodrie, LA, October, 1991. Texas Sea Grant Publications TAMU-SG92-109. Texas A\&M University, College Station, p. 84-94

Berounsky, V. M., Nixon, S. W. (1990). Temperature and the annual cycle of nitrification in waters of Narragansett Bay. Limnol. Oceanogr. 35: 1610-1617

Biddanda, B., Opsahl, S., Benner, R. (1994). Plankton respiration and carbon flux through the bacterioplankton on the Louisiana shelf. Limnol. Oceanogr. 39: 1259-1275

Bjørnsen, P. K. (1986). Bacterioplankton growth yield in continuous seawater cultures. Mar. Ecol. Prog. Ser. 30: 191-196 
Bratkovich, A., Dinnel, S. P. (1992). Lower Mississippi River historical nitrate flux and Mississippi River outflow buoyancy flux. Proceedings of the NOAA Nutrient Enhanced Coastal Ocean Productivity Synthesis Workshop, Cocodrie, LA, October, 1991. Texas Sea Grant Publications TAMU-SG-92-109. Texas A\&M University, College Station, p. 37-42

Bronk, D., Glibert, P. M. (1993). Application of a ${ }^{15} \mathrm{~N}$ tracer method to the study of dissolved organic nitrogen uptake during spring and summer in Chesapeake Bay. Mar. Biol. 115: 501-508

Carpenter, J. H. (1965). The Chesapeake Bay Institute technique for the Winkler dissolved oxygen method. Limnol. Oceanogr. 10: 135-140

Chin-Leo, G., Benner, R. (1992). Enhanced bacterioplankton production and respiration at intermediate salinities in the Mississippi River plume. Mar. Ecol. Prog. Ser. 87: 87-103

Corner, E. D. S., Newell, B. S. (1967). On nutrition and metabolism of zooplankton. IV. The forms of nitrogen excreted by Calanus. J. mar. biol. Ass. U.K. 47: 259-270

Cotner, J. B., Gardner, W. S. (1993). Heterotrophic bacterial mediation of ammonium and dissolved free amino acid fluxes in the Mississippi River Plume. Mar. Ecol. Prog. Ser. 93: $75-87$

Dagg, M. J., Ortner, P. B. (1992). Mesozooplankton grazing and the fate of carbon in the Northern Gulf of Mexico. Proceedings of the NOAA Nutrient Enhanced Coastal Ocean Productivity Synthesis Workshop, Cocodrie, LA, October, 1991. Texas Sea Grant Publications TAMU-SG-92-109. Texas A\&M University, College Station, p. 117-121

Dagg, M. J., Whitledge, T. E. (1991). Concentrations of copepod nauplii associated with the nutrient-rich plume of the Mississippi River. Cont. Shelf Res. 11: 409-423

Dickson, A. G., Goyet, C. (1991). Handbook of methods for the analysis of the various parameters of the $\mathrm{CO}_{2}$ system in the sea. U.S. Dept of Energy, Washington, DC

Dortch, Q. (1994). Changes in phytoplankton numbers and species composition. In: Dowgiallo, M. J. (ed.) Coastal oceanographic effects of 1993 Mississippi River flooding. Special NOAA Report. NOAA Coastal Ocean Office/ National Weather Service, Silver Spring, MD, p. 46-49

Dortch, Q., Bode, A., Twilley, R. R. (1992a). Nitrogen uptake and regeneration in the surface waters of the Louisiana continental shelf influenced by the Mississippi River. Proceedings of the NOAA Nutrient Enhanced Coastal Ocean Productivity Synthesis Workshop, Cocodrie, LA, October, 1991. Texas Sea Grant Publications TAMU-SG-92-109. Texas A\&M University, College Station, p. 52-56

Dortch, Q., Milsted, D., Rabalais, N. N., Lohrenz, S. E., Redjalde, D. G., Dagg, M., Turner, R. E., Whitledge, T. (1992b). Role of silicate availability in phytoplankton species composition and the fate of carbon. Proceedings of the NOAA Nutrient Enhanced Coastal Ocean Productivity Synthesis Workshop, Cocodrie, LA, October, 1991. Texas Sea Grant Publications TAMU-SG-92-109. Texas A\&M University, College Station, p. 76-83

Dugdale, R. C., Goering, J. J. (1967). Uptake of new and regenerated forms of nitrogen in marine production. Limnol. Oceanogr. 12: 196-206

Fahnenstiel, G. L., Marcovitz, M. H., McCormick, M. J., Redalje, D. G., Lohrenz, S. E., Carrick, H. J., Dagg, M. J. (1992). High growth and microzooplankton-grazing loss rates for phytoplankton populations from the Mississippi River plume region. Proceedings of the NOAA Nutrient Enhanced Coastal Ocean Productivity Synthesis Workshop, Cocodrie, LA, October, 1991. Texas Sea Grant Pub- lications TAMU-SG-92-109. Texas A\&M University, College Station, p. 111-116

Feliatra, F., Bianchi, M. (1993). Rates of nitrification and carbon uptake in the Rhône River Plume (Northwest Mediterranean Sea). Microb. Ecol. 26: 21-28

Fox, L. E., Lipshultz, L., Kerof, L., Wofsy, S. C. (1987). A chemical survey of the Mississippi estuary. Estuaries 10: 1-12

Gardner, W. S., Benner, R., Chin-Leo, G., Cotner, J. B. Jr, Eadie, B., Cavaletto, J. F., Lansing, M. B. (1994). Mineralization of organic matter and bacterial dynamics in Mississippi River plume water. Estuaries 17: 816-828

Gardner, W. S., Cotner, J. B., Herche, L. R. (1993). Chromatographic measurement of nitrogen mineralization rates in marine coastal waters with ${ }^{15} \mathrm{~N}$. Mar. Ecol. Prog. Ser, 93: $65-73$

Gaston, G. R. (1985). Effects of hypoxia on macrobenthos of the inner shelf off Cameron, Louisiana. Estuar. coast. Shelf Sci. 20: 603-613

Granéli, W., Granéli, E. (1991). Automatic potentiometric determination of dissolved oxygen. Mar. Biol. 108: 341-348

Griffith, P. C., Douglass, D. J., Wainwright, S. C. (1990). Metabolic activity of size-fractionated microbial plankton in estuarine, nearshore, and continental shelf waters of Georgia. Mar. Ecol. Prog. Ser. 59: 263-270

Harper, D. E. Jr, McKinney, L. D., Salzer, R. R., Case, R. J. (1981). The occurrence of hypoxic bottom water off the upper Texas coast and its effect on the benthic biota. Contr. mar. Sci. 24: 53-79

Hecky, R. E., Campbell, P., Hendzel, L.L. (1993). The stoichiometry of carbon, nitrogen and phosphorus in particulate matter of lakes and oceans. Limnol. Oceanogr. 38: 709-724

Hecky, R. E., Kilham, P. (1988). Nutrient limitation of phytoplankton in freshwater and marine environments: a review of recent evidence on the effects of enrichment. Limnol. Oceanogr. 33: 796-882

Hitchcock, G., Whitledge, T. (1992). Nutrient/pigment variability in the Mississippi River plume and adjacent waters. Proceedings of the NOAA Nutrient Enhanced Coastal Ocean Productivity Synthesis Workshop, Cocodrie, LA October, 1991. Texas Sea Grant Publications TAMU-SG92-109. Texas A\&M University, College Station, p. 43-51

Hopkinson, C. S., Sherr, B., Wiebe, W. J. (1989). Size fractionated metabolism of coastal microbial plankton. Mar. Ecol. Prog. Ser. 51: 155-166

Iriarte, A., Daneri, G., Garcia, V. M. T., Purdie, D. A., Crawford, D. W. (1991). Plankton community respiration and its relationship to chlorophyll a concentration in marine coastal waters. Oceanol. Acta 14: 379-388

Jensen, L. M., Sand-Jensen, K., Marcher, S., Hansen, M. (1990). Plankton community respiration along a nutrient gradient in a shallow Danish estuary. Mar. Ecol. Prog. Ser. 61: $75-85$

Johnstone, B. H., Jones, R. D. (1989). A study on the lack of $\left[\right.$ methyl- $\left.{ }^{3} \mathrm{H}\right]$ thymidine uptake and incorporation by chemolithotrophic bacteria. Microb. Ecol. 18: 73-77

Jumars, P. A., Penry, D. L., Baross, J. A., Perry, M. J., Frost, B. W. (1989). Closing the microbial loop: dissolved carbon pathway to heterotrophic bacteria from incomplete digestion and absorbance in animals. Deep Sea Res. 36: 483-495

Kauffman, Z. G., Lively, J. S., Carpenter, E. J. (1983). Uptake of nitrogenous nutrients by phytoplankton in a barrier island estuary: Great South Bay, New York. Estuar, coast. Shelf Sci. 17: 483-493

Kirchman, D. L., K'nees, E., Hodson, R. (1985). Leucine incorporation and its potential as a measure of protein 
synthesis by bacteria in natural aquatic systems. Appl. environ. Microbiol. 49: 599-607

Kirchman, D., Soto, Y., Van Wambeck, F., Bianchi, M. (1989). Bacterial production in the Rhône River plume: effect of mixing on relationships among microbial assemblages. Mar. Ecol. Prog. Ser. 53: 267-275

Kristiansen, S. (1983). Urea as a nitrogen source for the phytoplankton in the Oslofjord. Mar. Biol. 74: 17-24

Lampert, W. (1978). Release of dissolved organic carbon by grazing zooplankton. Limnol. Oceanogr. 23: 831-834

Lipshultz, F., Wofsy, S. C., Fox, L. E. (1986). Nitrogen metabolism of the eutrophic Delaware River ecosystem. Limnol. Oceanogr. 31: 701-716

Lohrenz, S. E., Dagg, M. J., Whitledge, T.E. (1990). Enhanced primary production at the plume/oceanic interface of the Mississippi River. Cont, Shelf Res. 7: 639-664

Lohrenz, S. E., Redjalde, D. G., Fahnenstiel, G. L, Lang, G. A. (1992). Regulation and distribution of primary production in the northern Gulf of Mexico. Proceedings of the NOAA Nutrient Enhanced Coastal Ocean Productivity Synthesis Workshop, Cocodrie, LA, October, 1991. Texas Sea Grant Publications TAMU-SG-92-109. Texas A\&M University, College Station, p. 95-104

Lopez-Veneroni, D., Cifuentes, L. A. (1992). Dissolved organic nitrogen distribution and transport in the continental shelf of the northwest Gulf of Mexico. Proceedings of the NOAA Nutrient Enhanced Coastal Ocean Productivity Synthesis Workshop, Cocodrie, LA, October, 1991. Texas Sea Grant Publications TAMU-SG-92-109. Texas A\&M University, College Station, p. 57-68

McCarthy, J. J. (1970). A urease method for urea in seawater. Limnol. Oceanogr. 15: 309-312

McCarthy, J. J. (1972). The uptake of urea by natural populations of marine phytoplankton. Limnol. Oceangr. 17: 738-748

Oudot, C., Gerard,.R., Morin, P., Gningue, I. (1988). Precise shipboard determination of dissolved oxygen (Winkler procedure) for productivity studies with a commercial system. Limnol. Oceanogr. 33: 146-150

Owens, N. J. K. (1986). Estuarine nitrification: a naturally occurring fluidized bed reaction? Estuar. coast. Shelf Sci. 22: $31-44$

Packard, T. T. (1979). Respiration and respiratory electron transport activity in plankton from the Northwest African upwelling area. J. mar. Res. 37: 711-742

Pavela, J. S., Ross, J. L., Chittenden, M. E. Jr (1983). Sharp reductions in abundances of fishes and benthic macro-

This article was presented by S. Y. Newell (Senior Editorial Advisor), Sapelo Island, Georgia, USA invertebrates in the Gulf of Mexico off Texas associated with hypoxia. Northeast Gulf Sci. 6: 167-173

Pomeroy, L. R., Sheldon, J. E., Sheldon, W. M. (1994). Changes in bacterial numbers and leucine assimilation during estimations of microbial respiratory rates in seawater by the precision Winkler method. Appl. environ. Microbiol. 60: 328-332

Porter, K. G., Feig, Y. S. (1980). The use of DAPI for identifying and counting aquatic microflora. Limnol. Oceanogr. 25: $943-948$

Remsen, C. C. (1971). The distribution of urea in coastal and oceanic waters. Limnol. Oceanogr. 16: 732-740

Renard, M. (1986). Hypoxia in Louisiana coastal waters during 1983: implications for fisheries. Fish. Bull. 84: $19-26$

Riley, G. A. (1937). The significance of the Mississippi River drainage for biological conditions in the northern Gulf of Mexico. J. mar. Res. 1: 60-74

Ryther, J. H., Dunstan, W. M. (1971). Nitrogen, phosphorus and eutrophication in the coastal marine environment. Science 171: 1008-1013

Simon, M., Azam, F. (1989). Protein content and protein synthesis rates of planktonic marine bacteria. Mar. Ecol. Prog. Ser. 51: 201-213

Turner, R. E., Rabalais, N. N. (1991). Changes in Mississippi River water quality this century. BioSci. 41: 140-147

Vidal, J., Whitledge, T. E. (1982). Rates of metabolism of planktonic crustaceans as related to body weight and temperature of habitat. J. Plankton Res. 4: 77-84

Ward, B. B., Kilpatrick, K. A., Renger, E. H., Eppley, R. W. (1989). Biological nitrogen cycling in the nitricline. Limnol. Oceanogr. 34: 493-513

Whitledge, T. E., Malloy, S. C., Patton, C. J., Wirick, C. D. (1981). Automated nutrient analysis in seawater. Formal Report 51398, Brookhaven National Laboratory, Upton, NY

Williams, P. J. LeB. (1981). Microbial contribution to overall marine plankton metabolism: direct measurements of respiration. Oceanol. Acta 4: 359-364

Williams, P. J. LeB. (1984). A review of measurements of respiration rates of marine plankton populations. In: Hobbie, J. E., Williams, P. J. LeB. (eds.) Heterotrophic activity in the sea. Plenum Press, New York, p. $357-389$

ZoBell, C. E., Feltham, C. B. (1935). The occurrence of ureasplitting bacteria in the sea. Science 81: 234-236

Manuscript first received: April 19, 1994

Revised version accepted: August 31, 1994 